\title{
Specific Identification of Biomphalaria tenagophila and Biomphalaria occidentalis Populations by the Low Stringency Polymerase Chain Reaction
}

\author{
Edina Rodrigues Pires, Teofânia HDA Vidigal, Horácio MS Teles*, \\ Andrew JG Simpson**, Omar S Carvalho/ ${ }^{+}$
}

Laboratório de Helmintoses Intestinais, Centro de Pesquisas René Rachou-FIOCRUZ, Caixa Postal 1743, 30190-002 Belo Horizonte, MG, Brasil *Superintendência de Controle de Endemias, São Paulo, SP, Brasil

**Laboratório de Genética de Câncer, Instituto Ludwig de Pesquisa sobre o Câncer, São Paulo, SP, Brasil

Although Biomphalaria occidentalis and B. tenagophila are indistinguishable on the basis of shell morphology and the majority of their genital organs, only the latter is susceptible to infection with Schistosoma mansoni. Thus, the identification of these species is fundamental to epidemiological studies of schistosomiasis. Here we describe a simple and rapid method for differentiating B. tenagophila from B. occidentalis based on low stringency polymerase chain reaction and using a pair of primers specific for the amplification of the $18 S$ rRNA gene. Analysis of the low stringency product profiles of populations of these snails from different geographical regions confirmed this approach as being applicable to the identification of $\mathrm{B}$. tenagophila and $\mathrm{B}$. occidentalis in cases where classical morphology is inconclusive.

Key words: polymerase chain reaction - low stringency - Biomphalaria tenagophila - Biomphalaria occidentalis schistosomiasis

Paraense (1981), described Biomphalaria occidentalis, a species which could not be differentiated from B. tenagophila by shell characteristics and by the morphology of most genital organs. The same author showed that in the laboratory, the two species are separated by absolute reproductive isolation. The differentiation of the two species can be accomplished only by careful dissection of the male and female genitalia and the demonstration of the presence of a vaginal pouch in $B$. tenagophila and its absence in $B$. occidentalis (Paraense 1981). B. occidentalis has never been successfully infected by the trematode Schistosoma mansoni (Paraense \& Côrrea 1982, Coimbra \& Engel 1982), and the identification of these species is important for the epidemiology and control of schistosomiasis mansoni. Bailey et al. (1986) used electrophoresis of the hemolymphs of these snails in agarose gel in order to differentiate them. Mascara and Morgante (1995) proposed isoenzyme

\footnotetext{
Work partially supported by Fundação de Amparo à Pesquisa de Minas Gerais (FAPEMIG) and Coordenação de Aperfeiçoamento de Pessoal de Nível Superior (CAPES).

${ }^{+}$Corresponding author. Fax: +55-31-295.3115

Received 6 May 1996

Accepted 16 August 1996
}

patterns that might contribute to the identification of these molluscs. An alternative, and indeed very powerful, method to study the genetics of molluscs is the polymerase chain reaction (PCR). A modification of this technique is the random amplification of polymorphic DNA (RAPD), by which complex and informative genomic fingerprints can be readily generated without prior sequence determination (Williams et al. 1990, Welsh \& McClelland 1990). This technique has already been used in the study of molluscs for the identification of Bulinus species (Langand et al. 1993) and in analysis of genetic variability of $B$. glabrata populations (Vidigal et al. 1994). A related methodology, described by Dias-Neto et al. (1993), was named low stringency PCR (LS-PCR ). This method has been used for sex determination in $S$. mansoni, for the identification of Leptospira serovars (Caballero et al. 1994) and more recently in identification of $B$. glabrata and B. tenagophila (Vidigal et al. 1996). LS-PCR utilizes specific primers under LS conditions, in contrast to AP-PCR (arbitrarily primed PCR) where the choice of primer is arbitrary, although the conditions of the reaction remain the same. The result of complex LS-PCR amplification is a specific fragment defined by the primer used, together with a complex set of other fragments (known as LS products or LSPs) derived from LS interactions of the primers with other sequences in the target genome. Here we have used 
LS-PCR with specimens of B. tenagophila and $B$. occidentalis from different geographical regions of Brazil showing that distinct profiles are consistently produced which distinguish these two planorbid species.

\section{MATERIALS AND METHODS}

Snail populations - The studies were undertaken using seven populations of B. tenagophila and six of $B$. occidentalis from different geographical regions of Brazil (Fig. 1).

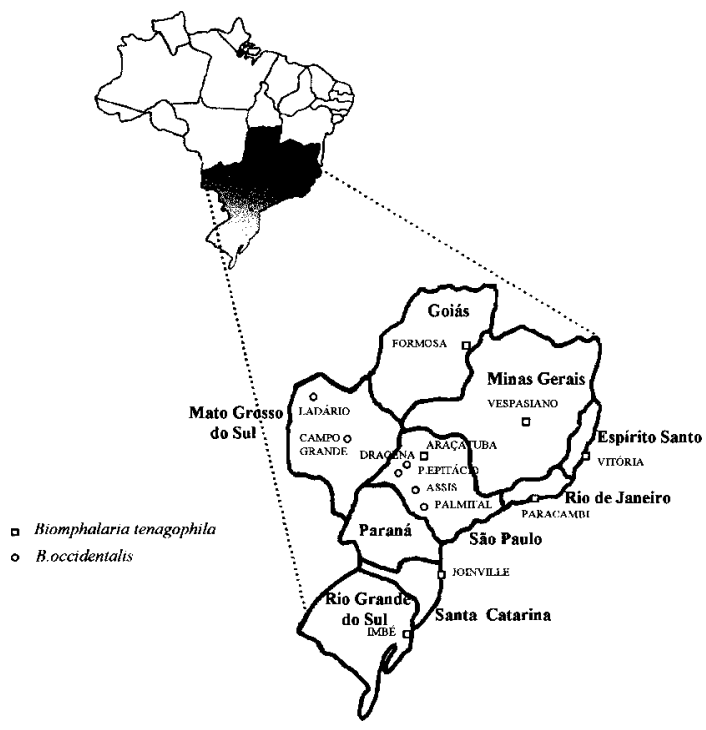

Fig. 1: map of the regions in Brazil showing the origin of the snail isolates (see Table)
These snails were maintained in the Departamento de Malacologia, Instituto Oswaldo Cruz, Rio de Janeiro, except the specimens of $B$. occidentalis from Dracena, Assis, Presidente Epitácio and Palmital, State of São Paulo, which were maintained in the Departamento de Malacologia, Superintendência de Controle de Endemias. The snails from Campo Grande and Ladário, State of Mato Grosso do Sul and Vespasiano, State of Minas Gerais, were collected directly from the field. The dates of collections, descriptions of the sites and origin of the specimens are shown in the Table.

All the snails used in the study were reared and maintained at room temperature under identical conditions in aquaria with running water and sterilized earth, sand, and calcium carbonate. The snails were exposed to artificial diurnal lighting for 10 $\mathrm{hr}$ and fed with lettuce. In all cases, the snails were identified by means of comparative morphology based on the reproductive organs and shells (Paraense 1975). The snails were examined in order to determine whether they released any type of cercaria and none were found to be infected by $S$. mansoni or other trematodes.

Preparation of DNA - Total DNA was extracted from the foot of the snails basically as described for B. glabrata by Vidigal et al. (1994). Briefly, the foot of each snail was mechanically disrupted in $50 \mathrm{mM}$ Tris $\mathrm{HCl}$ ph $8.0,100 \mathrm{mM} \mathrm{NaCl}, 50 \mathrm{mM}$ EDTA, $0.5 \%$ SDS and incubated with $50 \mathrm{mg} / \mathrm{ml}$ proteinase $\mathrm{K}$ overnight at $37^{\circ} \mathrm{C}$. Following phenol/chloroform extraction and ethanol precipitation, DNA was resuspended in $10 \mathrm{mM}$ Tris-HCl, 1 $\mathrm{mM}$ EDTA $\mathrm{pH} 8.0$ and the DNA concentration estimated by comparison with known quantitative standards in $1.5 \%$ ethidium bromide stained agar-

TABLE

Dates of collection of the snails used

\begin{tabular}{|c|c|c|c|}
\hline Species (Biomphalaria) & Origin & Site & Date of collection \\
\hline B. tenagophila & Paracambi & Stream & May, 1990 \\
\hline B. tenagophila & Imbé & N.A. & N.A. \\
\hline B. tenagophila & Araçatuba & N.A. & May, 1981 \\
\hline B. tenagophila & Formosa & N.A. & August, 1981 \\
\hline B. tenagophila & Vespasiano & Stream & May, 1994 \\
\hline B. tenagophila & Joinvile & N.A. & N.A. \\
\hline B. tenagophila & Vila Velha & N.A. & January, 1983 \\
\hline B. occidentalis & Campo Grande & N.A. & September, 1995 \\
\hline B. occidentalis & Ladário & N.A. & September, 1995 \\
\hline B. occidentalis & Assis & Stream & October, 1993 \\
\hline B. occidentalis & Dracena & Stream & January, 1994 \\
\hline B. occidentalis & Palmital & Stream & June, 1993 \\
\hline B. occidentalis & Presidente Epitácio & Stream & July, 1989 \\
\hline
\end{tabular}

N.A. = not available 
ose gels. A one nanogram template DNA was utilized for each reaction of the PCR.

DNA amplification by LS-PCR - The protocol used was that previously applied for the study of sex differentiation in S. mansoni (Dias-Neto et al. 1993). DNA samples from each individual were amplified using $1 \mathrm{ng}$ of template DNA. Each reaction was undertaken in a final volume of $10 \mathrm{ml}$ containing 0.8 units of Taq DNA polymerase (Cenbiot, RS, Brazil), $200 \mathrm{mM}$ each dNTP, $1.5 \mathrm{mM} \mathrm{MgCl} 2$, $50 \mathrm{mM} \mathrm{KCl}, 10 \mathrm{mM}$ Tris-HCl, $\mathrm{pH} 8.5$, together with 3.2 pmoles of the primers ET1 (5'GTCCAGACACTACGGGAAT-3') and NS1 (5'TAGTCATATGCTTGTCTCAG-3'). The primers used are based on the sequence of the 18S rRNA gene from the bivalve mollusc Placopecten available in GenBank (access number X53899). The primers correspond to a conserved region of the gene and show a high degree of homology with human (access number X03205), S. mansoni (access number X53467), fungi (Neurospora crassa, access number X04971) and other 18S rRNA genes. The reaction mix was overlaid with $20 \mathrm{ml}$ of mineral oil and, following an initial denaturation at $95^{\circ} \mathrm{C}$ for $5 \mathrm{~min}$, was subjected to two cycles through the following temperature profile: $30^{\circ} \mathrm{C}$ for $2 \mathrm{~min}$ for annealing, $72^{\circ} \mathrm{C}$ for $1 \mathrm{~min}$ for extension and $95^{\circ} \mathrm{C}$ for $30 \mathrm{sec}$ for denaturation followed by 33 cycles where the annealing step was altered to $40^{\circ} \mathrm{C}$. In the final cycle, the extension step lasted $5 \mathrm{~min}$. For analysis of the snail amplification products, $3 \mathrm{ml}$ of the final reaction mix was applied to the gel. Electrophoresis was undertaken using 4\% polyacrylamide gels. Following the separation, the gels were fixed with $10 \%$ ethanol $/ 0.5 \%$ acetic acid for 5 min and DNA bands revealed by staining with $0.2 \%$ silver nitrate for $10 \mathrm{~min}$ and reduction with $0.75 \mathrm{M} \mathrm{NaOH} / 0.1 \mathrm{M}$ formaldehyde for $5 \mathrm{~min}$ as previously described (Santos et al. 1993, Sanguinetti et al. 1994).

\section{RESULTS}

We analyzed seven populations of $B$. tenagophila and six populations of $B$. occidentalis from different geographical regions of Brazil (Fig. 1). Fig. 2 shows a comparison of the LSP profiles produced from two individuals of $B$. tenagophila. Fig. 3 shows two individuals of $B$. occidentalis, collected from the different localities using the primer pair NS1 and ET1 and one nanogram template DNA for each amplification. The LSP profiles were polymorphic for both species. However,

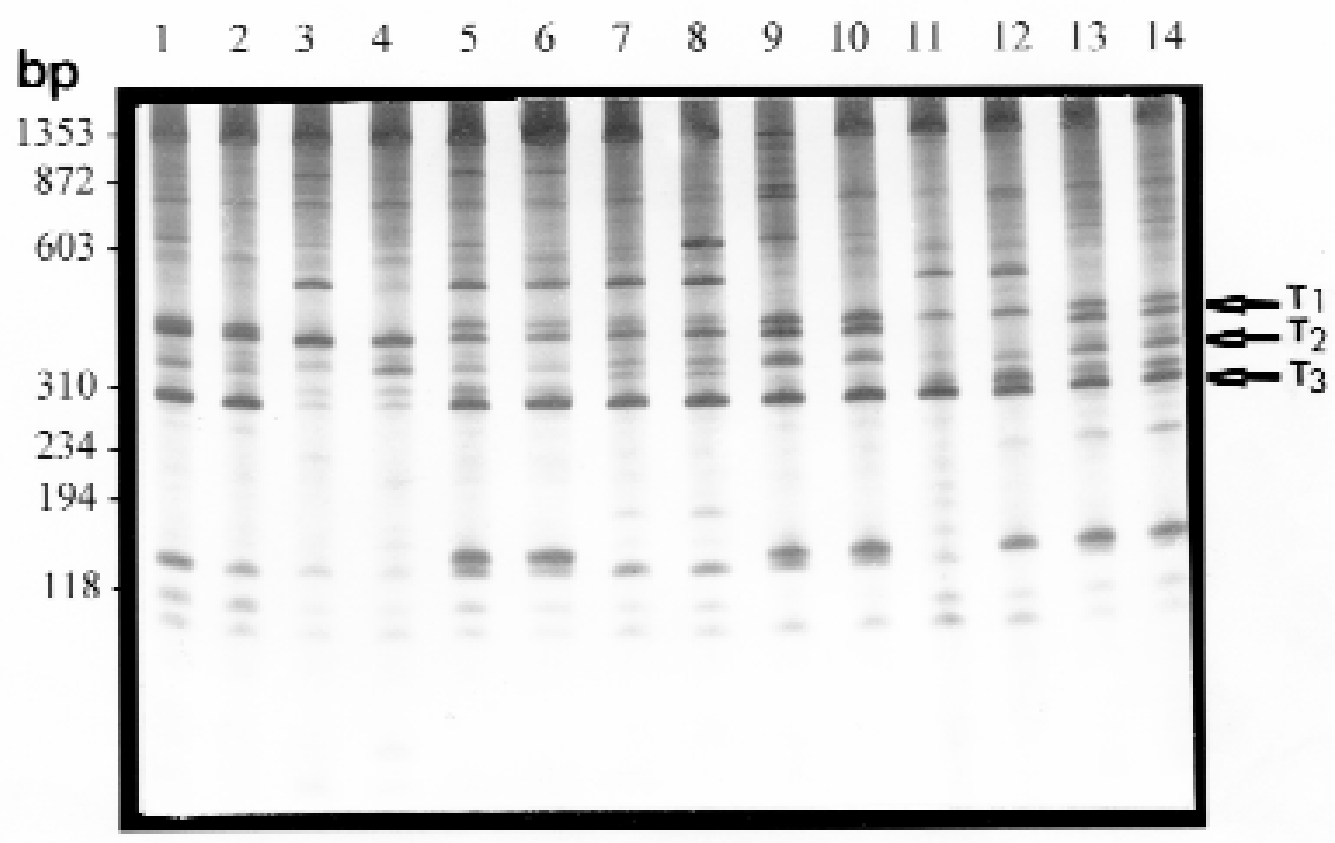

Fig. 2: comparison of LSP profiles of Biomphalaria tenagophila of different geographical regions obtained with the primer pair NS1-ET1 and $1 \mathrm{ng}$ of DNA template. Lanes 1 and 2 are representative of $B$. tenagophila specimens from Formosa, GO. Lanes 3 and 4: B. tenagophila specimens from Imbé, RS. Lanes 5 and 6: B. tenagophila specimens from Joinvile, SC. Lanes 7 and 8: $B$. tenagophila specimens from Araçatuba, SP. Lanes 9 and 10: B. tenagophila specimens from Vitória, ES. Lanes 11 and $12: B$. tenagophila specimens from Paracambi, RJ. Lanes 13 and 14: B. tenagophila specimens from Vespasiano, MG. The LS-PCR amplification products were visualized in a $4 \%$ polyacrylamide gel stained with silver. 


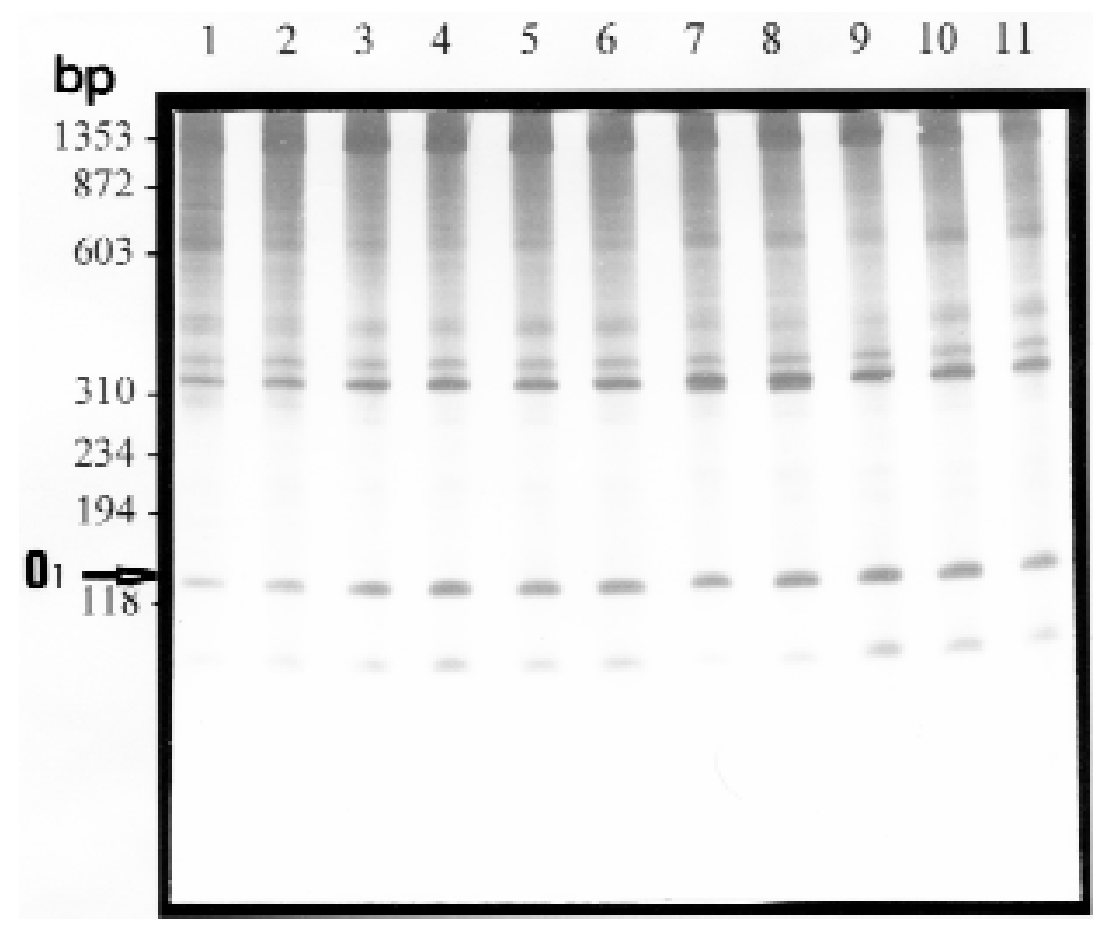

Fig. 3: comparison of LSP profiles of Biomphalaria occidentalis obtained with the primer pair NS1-ET1 and $1 \mathrm{ng}$ of DNA template. Lanes 1 and 2: B. occidentalis specimens from Campo Grande, MS. Lanes 3 and 4: B. occidentalis specimens from Ladário, MS. Lanes 5 and 6: B. occidentalis specimens from Assis, SP. Lanes 7 and 8: B. occidentalis specimens from Dracena, SP. Lanes 9 and 10: B. occidentalis specimens from Palmital, SP. Lane 11: B. occidentalis specimen from Presidente Epitácio, SP. The LS-PCR amplification products were visualized in a $4 \%$ polyacrylamide gel stained with silver.

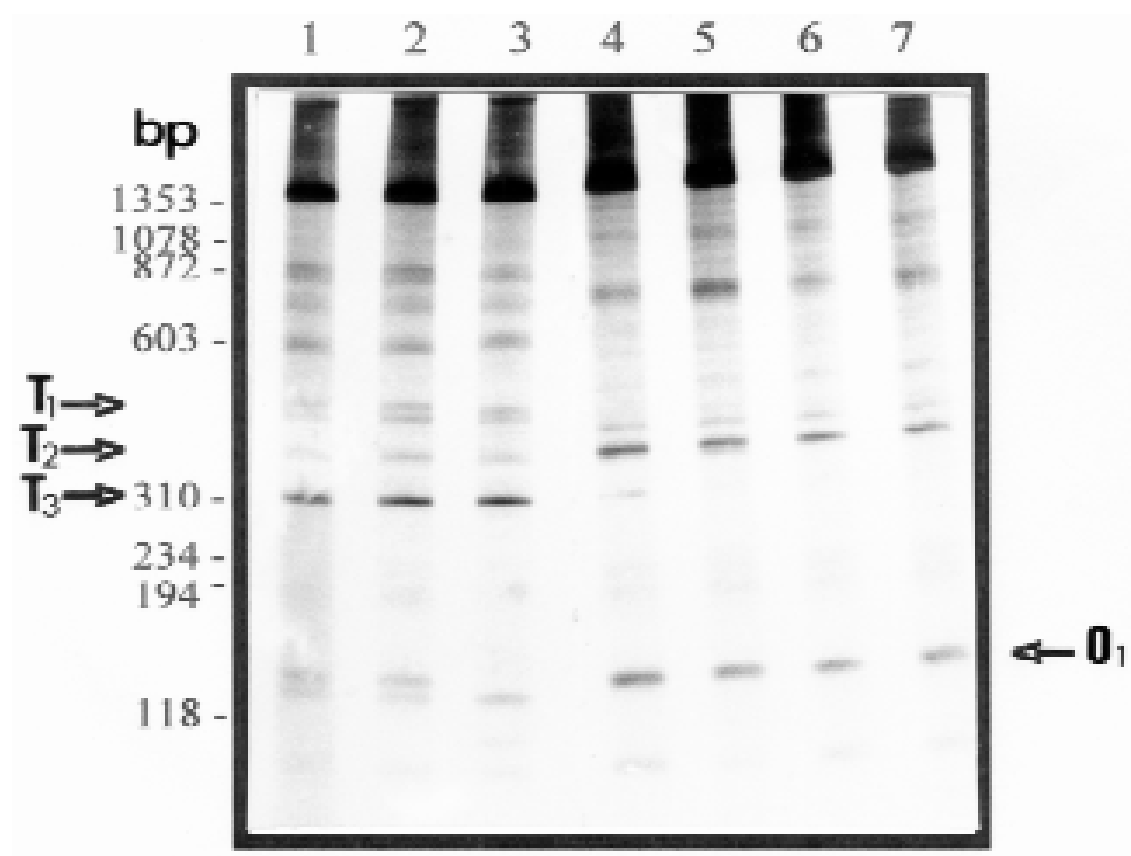

Fig. 4: comparison of LSP of profiles of Biomphalaria occidentalis and B. tenagophila obtained with the primer pair NS1-ET1 and $1 \mathrm{ng}$ of DNA template. Lane 1 to 3: B. tenagophila specimens from Vespasiano; MG, Vitória; ES and Joinvile; SC, respectively. Lanes 4 to 7: B. occidentalis specimens from Campo Grande; MS, Ladário; MS; Assis; SP and Dracena; SP, respectively. The LS-PCR amplification products were visualized in a $4 \%$ polyacrylamide gel stained with silver. 
a number of bands were consistently amplified from all the specimens of each species. The $B$. tenagophila specimens were characterized by the presence of three LSP: of $500 \mathrm{bp}$ (T1), $400 \mathrm{bp}$ (T2) and $310 \mathrm{bp}$ (T3). The B. occidentalis specimens were characterized by the presence of one LSP of 130 bp (O1). Fig. 4 shows a reduced number of specimens of each species run on the same gel to demonstrate their different LSPs profiles: $B$. tenagophila continued presenting the three characteristics bands (T1, T2 and T3) and the $B$. occidentalis one characteristic band $(\mathrm{O} 1)$.

\section{DISCUSSION}

The identification of B. tenagophila and $B$. occidentalis is difficult because these species are very similar and cannot be differentiated by shell characteristics or by the morphology of most of the genital organs (Paraense 1981). Thus, alternative approaches are required.

Bailey et al. (1986), used hemolymph analyzed by agarose gel electrophoresis in an attempt to separate these species but this approach demonstrated that B. glabrata and B. straminea could not be separated. Mascara and Morgante (1995) demonstrated that isoenzyme analysis may contribute to the identification of these two species of snails. These authors observed that the value of these techniques is questionable for taxonomic studies because quantitative and qualitative variations are associated with the age and size of individual snails.

The use of PCR provides a new method for the study of molluscs at the genomic level and has been used with success in the study of the genetic variability of Bulinus and B. glabrata populations (Langand et al. 1993, Vidigal et al. 1994), and in two species of marine gastropods: Littorina saxalitis and L. arcana (Crossland et al. 1993).

In the present study, LS-PCR was used as an approach to the identification of B. tenagophila and B. occidentalis. Analysis of the results with specimens obtained from widely separated localities probed with a pair of primers specific for the rRNA gene (NS1-ET1) indeed shows that these two species can be readily distinguished by this technique. It is noteworthy that in both cases, although there are polymorphisms, the LSP profiles are relatively consistent, facilitating identification and suggesting a reduced level of genetic variation in these species as compared with B. glabrata (Vidigal et al. 1994). The profiles of the two species, while allowing identification, are generally quite similar. This is consistent with the close phylogenetic relationship of the two species and, at a practical level, demonstrates that the test should be employed using standards and coelectrophoresis on the same gel to avoid errors.

\section{ACKNOWLEDGMENTS}

To Dr Wladimir Lobato Paraense and Dr Ligia Corrêa from the Departamento de Malacologia, Instituto Oswaldo Cruz, for providing the snails. To Cristiana Brito, Rosane Sturzeneker, Emmanuel Dias Neto and Patrícia Pinto from the Centro de Pesquisas René Rachou, by their invaluable advice and discussions, and Dr Álvaro Romanha for the facilities provided in the development of the project.

\section{REFERENCES}

Bailey JB, Michelson EH, Paraense WL 1986. Differentiation of the sibling species Biomphalaria occidentalis and Biomphalaria tenagophila by the electrophoretic patterns of their hemoglobin. Mem Inst Oswaldo Cruz 81: 319-322.

Caballero OLSD, Dias Neto E, Koury MC, Romanha AJ, Simpson AJG 1994. Low-Stringency PCR with diagnostically useful primers for identification of Leptospira serovars. J Clin Microbiol 32: 1369-1372.

Coimbra Jr CEA, Engel AL 1982. Suscetibilidade de Biomphalaria occidentalis do Acre e Mato Grosso à infecção pelo Schistosoma mansoni e sua implicação na epidemiologia da esquistossomose na Amazônia Ocidental, Brasil. Acta Amazônica 12: 795-799.

Crossland S, Coates D, Grahame J, Mill PJ 1993. Use of random amplified polymorphic DNAs (RAPDs) in separating two sibling species of Littorina. Mar Ecol Prog Ser 96: 301-305.

Dias Neto E, Santos FR, Pena SDJ, Simpson AJG 1993. Sex determination by Low Stringency PCR (LSPCR). Nucleic Acids Res 21: 763-764.

Langand J, Barral V, Delay B, Jourdane J 1993. Detection of genetic diversity within snail intermediate hosts of the genus Bulinus by using random amplified polymorphic DNA markers (RAPDs). Acta Trop 55: 205-215.

Mascara D, Morgante JS 1995. Use of isozyme patterns in the identification of Biomphalaria tenagophila (D' Orbigny, 1835) and B. occidentalis (Paraense, 1981) (Gastropoda: Planorbidae). Mem Inst Oswaldo Cruz 90: 359-366.

Paraense WL 1975. Estado atual da sistemática dos planorbídeos brasileiros. Arq Mus Nac Rio de Janeiro 55: $105-128$.

Paraense WL 1981. Biomphalaria occidentalis sp.n. from South America (Mollusca Basommatophora Pulmonata). Mem Inst Oswaldo Cruz 76: 199-211.

Paraense WL, Corrêa LR 1982. Unsusceptibility of Biomphalaria occidentalis to infection with a strain of Schistosoma mansoni. Mem Inst Oswaldo Cruz 77: 55-58.

Sanguinetti JC, Dias Neto E, Simpson AJG. 1994. Rapid Silver Staining and recovery of PCR products separated on polyacrylamide gels. BioTechniques 5: 915918.

Santos FR, Pena SDJ, Epplen JT 1993. Genetic and populational study of an Y-linked tetranucleotide repeat DNA polymorphism. Hum Genet 90: 655656. 
Vidigal THDA, Dias-Neto E, Carvalho OS, Simpson AJG 1994. Biomphalaria glabrata: extensive genetic variation in Brazilian isolates revealed by random amplified polymorphic DNA analysis. Exp Parasitol 79: 187-194.

Vidigal THDA, Dias-Neto E, Simpson AJG, Carvalho OS 1996. A low stringency polymerase chain reaction approach to identification of Biomphalaria glabrata and B. tenagophila intermediate snail hosts of Schistosoma mansoni in Brazil. Mem Inst Oswaldo Cruz (In press).

Welsh J, McClelland M 1990. Fingerprinting genomes using PCR with arbitrary primers. Nucleic Acids Res 18: 7213-7218.

Williams JGK, Kubelick AR, Livak KJ, Rafalski JA, Tingey SV 1990. DNA polymorphisms amplified by arbitrary primers are useful as genetic markers. Nucleic Acids Res 18: 6531-6535. 